\title{
TEACHER'S PERFORMANCE AND PRINCIPAL LEADERSHIP PATTERNS
}

\author{
Ucup Supriatna \\ STAI Al-Haudl Ketapang, Kalimantan Barat, Indonesia \\ kangucuptea@gmail.com
}

Submitted: 4/April/2021

Accepted: 8/April/2021

Publication: 9/April/2021

\begin{abstract}
The value of effective management in educational organizations is increasingly recognized by various stakeholders. The purpose of this study is to find out if the Head of Islamic Religious Education in Ketapang City uses an effective leadership pattern in managing his leadership. The findings of this study show that madrasah Aliyah level principals are effective leaders who understand how to be professional leaders. Professionally, this means that the head of Aliyah madrasa has established himself as an education leader and is committed to maintaining high standards at all times. In some cases, the head of Madrasah Aliyah falls into the category of master school leaders who are able to show quality in areas where others can place the principal. as a school leadership authority. The principal is not only good-looking, but also able to show an understanding of the concept of quality. However, no correlation was observed between the principal's leadership and student achievement levels. This indicates that the principal is an education leader with a professional or even a master's degree, but there is no relationship between leadership level and student learning achievement.
\end{abstract}

Keywords: Teacher Performance, Principal Leadership, Management Education, Islamic Education, Education Quality.

\section{Introduction}

Leadership is one of the most important factors in any organization. Some studies have also established that the leader factor plays an important role in organizational development. That the most critical factor of a leader is his character, as it is said that $90 \%$ of a leader's failures are caused by character failure(Kadir Fatimah St., 2014).

In general, and education management in particular, leadership is closely related to human resource management and shared management. In relation to human resource management, leaders or managers, along with employers and employees, are an integral component(Solekhah et al., 2018). Meanwhile, in the context of shared education management, leadership is one of eight critical factors for joint management practitioners. According to Deden Makbuloh, as cited in (Benson et al., 1991) eight important factors for joint management practitioners are as follows: 1) management leadership roles and quality policy; 2) the role of the quality department; 3) training; 4) product/service design; 5) supplier quality management; 6) process management; 7) quality data and reporting; and 8) employee relationships. As a result, the role of leadership management and the quality of policy formulation are closely related to shared management.

Total Quality Management can be used to improve the quality of education. Total Quality Management is a philosophy of continuous improvement in education, in which educational institutions provide a set of means or tools to meet, if not exceed, customer requirements, desires, and expectations today and in the future. (Ali \&Raza, 2017) is a way of doing business that aims to improve the competitiveness of the organization by continuously improving its service components, people, processes, and environment. Improving education 
together, on the other hand, can be the power of School-Based Management. Mutual School Based Management is an educational management approach that emphasizes more on the independence and creativity of the school.

The effective application of School-Based Management identifies several specific benefits: (a) empowering competent individuals in schools to make decisions that improve the quality of learning, (b) providing opportunities for all school residents to participate in making significant decisions, (c) encouraging creativity in designing learning programs, and (d) redirecting the average.

Both Total Quality Management and School-Based Management, on the other hand, will rely heavily on the leadership of the principal. The principal's primary responsibilities in carrying out his leadership responsibilities include three dimensions: leading a group of people, mobilizing material resources, and collaborating with others. Supplying skills, skills, and skills is an inevitability that the principal must have to operate the institution's machinery. According to (Indrafachrudi \&Tahalele, 1993), an educational institution leader must have at least five skills: 1) leadership ability; 2) interpersonal skills; 3) group management capabilities; 4) staffing administration capabilities; and 5) ability to judge.

To meet the demands associated with these expectations, the current principal should focus more on teaching and improving student learning, especially in measuring and determining student progress, than in previous periods. As a result, the current principal should focus on developing the school's vision, collaborating with other teachers, and encouraging the school to function as a student community (Pérez Garcias et al., 2017). Efforts to achieve expected improvements require the collection, processing, and assessment of data to determine what is needed, as well as monitoring teaching and curriculum to determine whether those needs have been properly met.

Some educational institutions face the problem of not being able to improve the quality of schools due to the lack of influential leaders in schools. According to (Stronge, 2018),effective leaders set direction and influence organization members to work together to achieve organizational goals. Principals can fulfill these responsibilities by providing individual support to teachers and delegating responsibility for reviewing teaching practices and adopting and implementing best practice models.

The findings revealed that one of the supporting factors and the key to the success of school achievement is the leadership or management of the principal / madrasah. According to research (Edmonds, 2020), schools that consistently improve work performance are led by good principals. According to the findings of the study (Nurdyansyah et al., 2017), there is a significant relationship between effective institutions and effective leadership. Edmonds also proposes that dynamic organizations are always led by good leaders, namely leaders who constantly strive to improve their achievements. According to the research (Ekosiswoyo, 2016), effective principals have a clear vision and are able to translate them into school goals that develop into great hopes for the future that are understood, lived, and realized by all school residents.

Understanding the need to improve the quality of madrasah education is also based on the fact that the development of science, technology, and culture today is more dominated and still in the hands of scientists, technologists, and cultural figures from western countries who are humanist - anthropocentric, and less caring, committed, and appreciative of teachings and fundamentalists While the Islamic education system is more on the periphery, even more consumptive.

To meet the demands associated with these expectations, the current principal should focus more on teaching and improving student learning, especially in measuring and determining student progress, than in previous periods. As a result, the current principal should focus on developing the school's vision, collaborating with other teachers, and encouraging the school to function as a learning community. Efforts to achieve expected improvements require the collection, processing, and assessment of data to determine what is needed, as well as monitoring teaching and curriculum to determine whether those needs have been properly met. This research focuses on efforts to understand and learn how to apply effective leadership indicators. The head of an Islamic boarding school in Ketapang, West Kalimantan, has research. 


\section{Research Method}

The research used highlights the performance of teachers and principals' leadership patterns. In this case, the authors carry out research using descriptive analysis methods with library research. The research design includes: 1) topic selection, 2) data exploration, 3) ensuring the research focus is based on the data that has been obtained, 4) the sources of information collected are in the form of empirical data or information sourced from articles, research reports and other literature. support the theme of this research, 5) Read library sources, 6) Make research notes, 7) Digest research notes, 8) Arrange reports. Information collection methods used are editing, organizing, and finding. On the other hand, for information analysis methods using deductive and interpretive analysis. Thus, the purpose of this research is to describe teacher performance and principal leadership patterns.

\section{Results and Discussion}

The conclusions in this article are written in such a way that examining all the author's announcements is based on the literature research procedures. The form will be displayed based on the author's findings from the literature search. Some comments and suggestions regarding the title of this objective article, such as an article that examines principal leadership Demonstrated the importance of leadership through their research findings. Significant for the ability of teachers, learning activities and forms of commitment can be mutually beneficial. The ability of the teacher is very influential(Juniarti et al., 2020). This means being a school teacher or educational institution who demonstrates the dedication and leadership style needed in education. If your principal has confirmed that you are a highly accomplished teacher in the institution then a teacher will feel comfortable teaching students and he will have strong abilities because he believes that the educational institution where he teaches provides efficient service and leadership and will produce good quality of learning According to the findings of the study (Kosim, 2017), leadership is required. A principal has the potential to benefit a teacher's ability to create and improve the quality of teaching while practicing. By strengthening the leadership and abilities of principals, it will produce better teacher quality and the quality of teaching will also increase and improve the quality of excellent education; student success in learning outcomes depends on the quality of teacher teaching. The performance of outstanding teachers is very important, because teachers have the ability to provide quality learning in schools and produce quality outputs. According to (Josanov-Vrgovic \&Pavlovic, 2014), the extent to which a teacher is satisfied with his profession is determined by the leadership style of the principal. The principal conveys a positive message Subordinates or teachers can communicate the consequences. Teacher outlets include school ties and peer to peer in professional development efforts. Research (Tambingon, 2018) shows it is necessary. for the principal's need for expertise and desire to mobilize and be responsible to his subordinates (teachers) when carrying out school-based learning activities. Teachers must be self-motivated and diligent. Professionals in the field of education Those who have the advantage of winning. Having the authority of the principal to influence teacher behavior and influence the principal's policy will be a model for the teacher. fulfill their responsibilities as educators. Teachers must be mobilized to develop into diligent, innovative, and possessive teachers. Unchanged in guiding clients towards successful results.

Based on research (H. Fitria et al., 2017; Y. Fitria, 2017) showed that the headmaster's leadership style forms a learning body and the form of organization affects the ability of teachers. It refers to the body shape that is based on the body learning is important. as a result of the fact that the form determines which team is built with the aim of preparing the concept in destination revenue through educational methods. Septiana and colleagues conducted research on this matter to support the findings of previous studies(Septiana \&Ivada, 2013). Each team is built according to its structure. Likewise, institutions must be able to do so. When each team member is able to carry out their responsibilities and demonstrate a high level of commitment, the leader will be more motivated to put forth additional effort. Good principal leadership can be seen from the pattern of good leadership in schools. They are able to lead and control the institutional situation as well as the strengths and weaknesses of each teacher so that they can 
make the right decisions. They are able to lead and control the institutional situation. the strengths and weaknesses of each teacher so that they can make the right decisions.

According to Iskandar's research (2013), the number of teachers will increase solely on the basis of loyalty and commitment, as well as individual abilities. That's very important. because the instructor believes that he has a responsibility to develop high-quality students and improve teaching materials for subjects that have developed into his responsibilities as an expert teacher(Iskandar, 2013).

Handayani and Rasyid's research (2015) showed that teacher skills are determined by the headmaster's leadership style and body habits, as well as the encouragement of the teacher's own activities. As with previous studies, the headmaster's positive actions and teacher evaluation encourage teachers to work harder to improve their professional results in order to contribute to the growth of teacher skills. Customs or culture of the body is also a factor that can affect a teacher's performance, because with a positive customary body, the teacher wants to be encouraged or feel the need to improve his ability so as not to be ignored by other activities. Body customs that apply to the obligation of the principal to create or produce a body culture that produces positive numbers for himself or his subordinates(Handayani \&Rasyid, 2015).

According to research conducted by isjuandi 2017 with the title of evaluation of education and training programs for prospective principals in North Kayong Regency, West Kalimantan Province, the results of this evaluation are seen from five perspectives, among others: 1) context, with relevance to the legal basis, management design, and training program objectives; 2) relevance results for legal basis, management design, and training program objectives; and 3) relevance results for legal basis, management design, and training program objectives. 2) Input on training participants, curriculum conformity, and funding, with related results for sub-aspects of program organizers in the excellent category ( 82.50 percent), resource persons/facilitators in the excellent category (79.69 percent), and facilities in the good category (71.74 percent). 3) process results: 77.92 percent received excellent assessment for time allocation, 74.40 percent received good assessment for curriculum and teaching materials, and 74.40 percent received good assessment for procedures and methods, monitoring and evaluation, as well as assessment of technical related processes. education and training guidelines for prospective principals. 4) product evaluation results, which include competencies in the form of relevant knowledge, attitude and behavior competencies (83.04 percent), skills (75.89 percent), and appointment as principals (high category) (86.30 percent). 5) the results of the evaluation of the impact of the program, in particular: the performance of graduates after being appointed positively with excellent categories (75.93 percent)(Isjuandi, 2017).

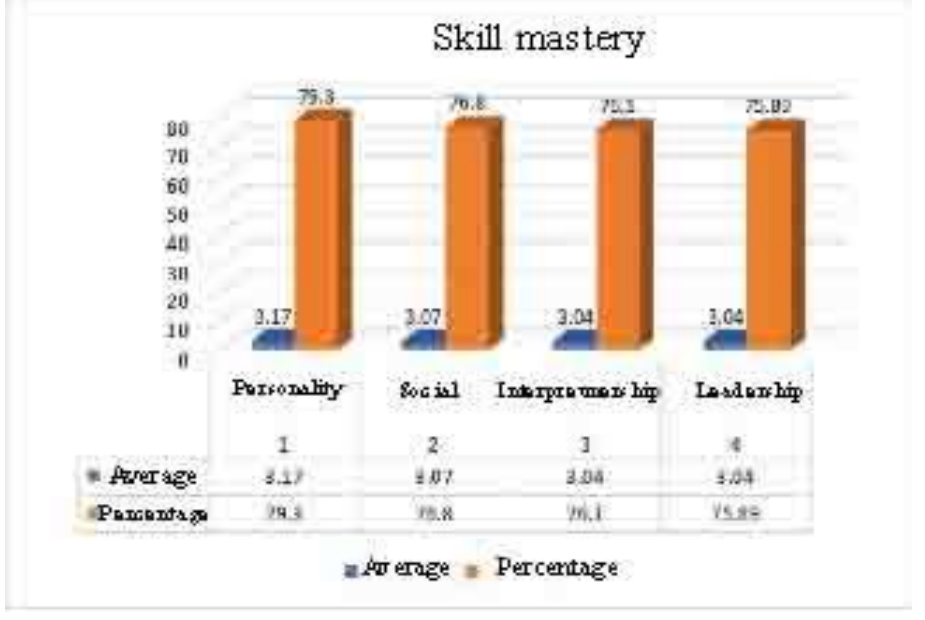

Figure 1. Mastery of Principal Skills 


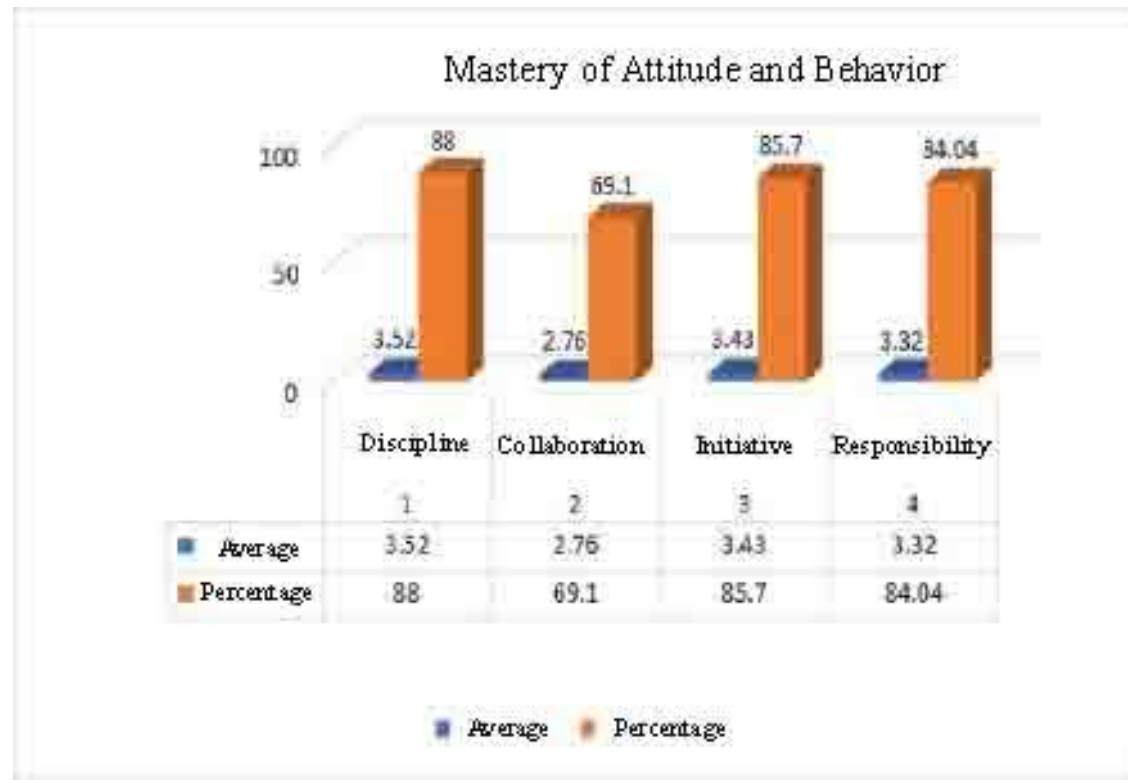

Figure 2. Mastery of Attitudes and Attitudes of the Principal

The review of the data outlined above shows that the headmaster's leadership style has a significant influence on teacher performance. An individual's capacity to lead an organization or educational institution is referred to as leadership. According to Hemhill and Coon in Triyono (2019), leadership is the behavior that a person has or practices to lead a certain type of activity or activity towards a common goal(Rahmawati, n.d.) . Based on some of the research findings above, one of the supporting factors to foster high teacher performance is the structure or leadership style of the principal in an educational institution or school. With an effective principal, teachers will be more motivated to carry out their responsibilities as educators. Arman et al. (2016) found that the competence of the principal is one of the factors that can affect the level of work motivation and teacher performance. The high level of competence of the principal can indirectly motivate the teacher due to the positive attitude of the principal and careful planning(ARMAN, 2016). Principals with a high level of competence or skills can adapt and be able to build a positive organizational culture with the aim of achieving superior quality both in the performance of their subordinates and the quality of the school as a whole.

Sagala (2018) argues that in order to instill the trust of subordinates (teachers) to the leader (principal), it is necessary to take birth and mental actions in line with intentions and words and communicate with teachers ethically(Sonedi et al., 2018). A leader or principal who has effective characteristics and leadership style is able to guide the members of the school organization he leads and direct the functions of the school towards educational objectives and school specific objectives. Various leadership models and styles have a significant impact on the ability of institutions or organizations to continue to exist. According to Maccoby in Triyono (2019), a leader is someone who is responsible for guiding, growing, and developing the motivations and potential of his subordinates thoroughly(Sonedi et al., 2018). This is reinforced by Kartini's opinion in Triyono (2019) which states that a leader is someone who has expertise and advantages in a particular field with these skills and advantages, the leader can persuade others or their members to collaborate in certain activities to achieve a predetermined goal. Every organization in this case needs transformational leadership. Transformational leadership is a concept of leadership or leadership style chosen by a leader (principal) to be applied in the institution (school) he leads with the aim of transforming or transforming into a new and better form and quality.

Transformational leadership can have a beneficial effect on a leader's relationship with his subordinates. Subordinates or teachers will develop admiration, trust, pride, and respect for their leader (principal) as a result of this leadership style, and will be motivated to carry out their responsibilities and duties in order to meet or exceed a predetermined target. Transformational 
leadership can be demonstrated in educational institutions or schools by changing the vision and strategy of achieving goals to be different from previous strategies. Principals who apply a transformational leadership style will generally innovate and transform a particular school, earning a reformist degree; In addition, the principal will be an exemplary figure, encouraging his subordinates to be more optimal in pursuing goals through motivation.

\section{Conclusion}

As a result of the foregoing, it can be concluded that how a leader or principal guides his or her subordinates or teachers in the school he or she leads has a direct impact on whether or not the teacher's performance improves. Second, motivation for teacher work is a critical factor in determining how well teachers perform. Third, teachers who are highly motivated in their work as educators will always feel the urgency and obligation to improve their performance. Fourth, job satisfaction is a factor that affects teacher performance; satisfaction with the positive attitude of the principal and the organizational structure established will be a motivator for teachers to continuously improve performance even beyond the initial standards; This is reinforced by the opinion (Octavia, 2019) that performance is a function of effort. If a teacher feels or gains inner satisfaction over the work he or she receives and produces, he will improve and develop(Octavia, 2019). Fifth, efforts to improve teacher performance can be made by involving teachers in education and training, evaluating teacher performance, and maintaining continuous communication between the principal and the teacher to analyze and solve problems that arise during the learning process for teachers. This ongoing communication can be one of the principal's efforts to improve the quality of education by paying attention to teacher performance. Susanto (2016) asserts that teacher performance management is inseparable from the responsibility of the principal, and with effective teacher performance management, the quality of education can be controlled and improved.

\section{References}

Ahmad Susanto, M. P. (2016). Teori belajar dan pembelajaran di sekolah dasar. Kencana.

Ali, M., \& Raza, S. A. (2017). Service quality perception and customer satisfaction in Islamic banks of Pakistan: the modified SERVQUAL model. Total Quality Management \& Business Excellence, 28(5-6), 559-577.

ARMAN, A. (2016). Pengaruh Kompetensi Pengawas Sekolah dan Kompetensi Kepala Sekolah Terhadap Motivasi Kerja dan Kinerja Guru SMP Negeri di Kabupaten Maros. Universitas Negeri Makassar.

Benson, P. G., Saraph, J. V., \& Schroeder, R. G. (1991). The Effects of Organizational Context on Quality Management: An Empirical Investigation. Management Science, 37(9), 11071124. https://doi.org/10.1287/mnsc.37.9.1107

Edmonds, R. (2020). Characteristics of effective schools. In The school achievement of minority children (pp. 93-104). Routledge.

Ekosiswoyo, R. (2016). Kepemimpinan kepala sekolah yang efektif kunci pencapaian kualitas pendidikan. Jurnal Ilmu Pendidikan, 14(2).

Fitria, H., Mukhtar, M., \& Akbar, M. (2017). The Effect of Organizational Structure And Leadership Style on Teacher Performance In Private Secondary School. IJHCM (International Journal of Human Capital Management), 1(02), 101-112.

Fitria, Y. (2017). Efektivitas capaian kompetensi belajar siswa dalam pembelajaran sains di sekolah dasar. Jurnal Inovasi Pendidikan Dan Pembelajaran Sekolah Dasar, 1(2), 34-42.

Handayani, T., \& Rasyid, A. A. (2015). Pengaruh kepemimpinan kepala sekolah, motivasi guru, dan budaya organisasi terhadap kinerja guru SMA negeri Wonosobo. Jurnal Akuntabilitas Manajemen Pendidikan, 3(2), 264-277.

Indrafachrudi, S., \& Tahalele, J. F. (1993). Mengantar Bagaimana Memimpin Sekolah Yang Baik.

Isjuandi, I. (2017). Evaluasi Program Pendidikan Dan Pelatihan Calon Kepala Sekolah Di Kabupaten Kayong Utara Provinsi Kalimantan Barat (Studi Evaluatif Model Cippo Pasca 
Pendidikan Dan Pelatihan). Jurnal Evaluasi Pendidikan, 8(2), 88-101. https://doi.org/10.21009/jep.082.04

Iskandar, U. (2013). Kepemimpinan kepala sekolah dalam peningkatan kinerja guru. Jurnal Visi Ilmu Pendidikan, 10(1).

Josanov-Vrgovic, I., \& Pavlovic, N. (2014). Relationship Between The School Principal Leadership Style And Teachers'job Satisfaction In Serbia. Montenegrin Journal of Economics, 10(1), 43.

Juniarti, E., Ahyani, N., \& Ardiansyah, A. (2020). Pengaruh Kepemimpinan Kepala Sekolah dan Disiplin Guru terhadap Kinerja Guru. Journal of Education Research, 1(3), 193-199.

Kadir Fatimah St. (2014). Keterampilan Mengelola Kelas Dan Implementasinya Dalam Proses Pembelajaran. Jurnal Al-Ta'dib, 7(2), 16-36.

Karacan, C. G., \& Akoğlu, K. (2021). Educational Augmented Reality Technology for Language Learning and Teaching: A Comprehensive Review. Shanlax International Journal of Education, 9(2), 68-79. https://doi.org/10.34293/education.v9i2.3715

Kosim, M. (2017). Pengaruh kepemimpinan kepala sekolah terhadap kinerja guru untuk mewujudkan mutu pembelajaran. Khazanah Akademia, 1(01), 30-38.

Nurdyansyah, N., Siti, M., \& Bachtiar, S. B. (2017). Problem Solving Model with Integration Pattern:Student's Problem Solving Capability. https://www.atlantispress.com/proceedings/icei-17/25892942

Octavia, S. A. (2019). Sikap dan Kinerja Guru Profesional. Deepublish.

Pérez Garcias, A., Tur, G., Negre Bennàssar, F., \& Lizana, A. (2017). Success factors of virtual university communities based on social networks. Analysis of XarFED. Revista Complutense de Educacion, 28(2). https://doi.org/10.5209/rev_RCED.2017.v28.n2.49568

Rahmawati, D. D. K. (n.d.). Peran Kepemimpinan Transformasional Kepala Sekolah Dalam Upaya Peningkatan Kinerja Guru.

Septiana, R., \& Ivada, E. (2013). Pengaruh kepemimpinan kepala sekolah dan motivasi kerja terhadap kinerja guru SMP Negeri Wonosari. Jupe-Jurnal Pendidikan Ekonomi, 2(1).

Solekhah, A. M., Athikah, T. P., \& Istiqomah, M. (2018). faktor-faktor yang mempengaruhi sikap empati terhadap perilaku prososial pada anak Sekolah Dasar. Universitas Negri Semarang, 0291.

Sonedi, S., Sholihah, T., \& Dihasbi, D. (2018). Peran Kepemimpinan Kepala Sekolah dalam Meningkatkan Kinerja Guru. Anterior Jurnal, 18(1), 13-22.

Stronge, J. H. (2018). Qualities of effective teachers. ASCD.

Tambingon, H. N. (2018). The influence of principal leadership style and teacher work motivation on the performance of certified teachers at SMA Negeri Kotamobagu, North Sulawesi, Indonesia. Journal of Education and Learning (EduLearn), 12(3). 